\title{
A reflective review on the creativity agenda in Korean education policy
}

\author{
[Yae-ji Hu, Kyunghee So, Jong-A Lee]
}

\begin{abstract}
The purpose of this study is to explore and discuss the formation and characteristics of the creativity agenda in Korean education policies. The research problems are as follows: 1) When and how did the creativity agenda emerge in education policy in Korea? 2) What are the features of the creativity agenda reflected in recent Korean education policies? To achieve these aim, the study analyzed governmental policy reports and press releases, reports from national research institutes, and national curriculum documents. According to the results of this study, the creativity agenda in education came to the forefront when the 5.31 Education Reform plan was declared with the purpose of responding to the diverse and fast-changing twenty-first century society. Creativity education before the 5.31 Education Reform was regarded as gifted education for only a few talented students. However, after the creativity agenda emerged in education policy, the range of target students for creativity education was expanded to include the majority of general students. Additionally, the creativity agenda exhibited diverse features during different governmental periods. In the first period, although creativity education for general students seemed declaratory in that it was still conducted within gifted education, creativity itself became a priority for the first time in Korea and attracted huge attention across the nation. In the second period, the creativity agenda for both gifted students and general students was emphasized, and the government tried to balance creativity education for both. Finally, in the third period, the creativity agenda has played an important role in education policies, and creativity education for general students is being actively implemented.
\end{abstract}

Keywords-Creativity, Creativity agenda, Korean education policy

\section{Introduction}

Recently, creativity has become one of the most essential agendas in education policy around the world (Craft, 2006) due to social changes such as the advent of a knowledgebased society and globalization. Following this trend, Korea has also placed great emphasis on creativity education not only to respond to new circumstances but also to solve its own educational problems. For instance, the focus on creativity in education is expected to improve the low level of satisfaction and interest in study among Korean students since creativity is considered to be a key factor in making learning more engaging and dynamic (Mindham, 2004).

Yae-ji Hu, Kyunghee So, Jong-A Lee/ Department of Education Seoul National University

Republic of Korea
Korea has put forth a lot of effort to implement relevant policies at the government level since the 5.31 Education Reform in 1995. However, it seems that "creativity education policies" have changed and embodied various characteristics in different governments. In this regard, there is a need to understand the creativity agenda from a historical perspective. The aims of this article are (1) to explore how the creativity agenda was formed and has been developed in the Korean context and (2) to discern the meanings and features of the creativity agenda since the 5.31 Reform.

\section{Methodology}

To achieve the aims of the research, the data sources were selected as follows: 24 policy reports or press releases from the Ministry of Education, 11 reports from national research institutes, and 10 national curricula, thus totaling 45 data sources.

The research is based on a "qualitative content analysis method" (Graneheim \& Lundman, 2004). The units of analysis are the documents mentioned above, most of which were published after 1995 when creativity education was on the rise. After repeated reading of the texts, 'meaning units', such as key words or phrases related to creativity education, were discovered. These meaning units were condensed into simpler concepts and then they were classified into several groups based on similarities. As a result, the researchers established "codes" and "categories," which are superordinate concepts to the codes.

\section{Results}

This chapter examines the formation of the creativity agenda in creativity education policies in the context of historical flow and then investigates some of the distinctive aspects of the creativity agenda which have appeared in its development process since the 5.31 Education Reform.

\section{A. The formation and development of the creativity agenda}

In the wake of major incidents such as the establishment of the Government of the Republic of Korea and the Korean War, the First and Second Republics (1948-1960) prioritized harmony between democracy and nationalism and the cultivation of an anticommunist spirit. Although creativity was not a major issue in education policy, it was mentioned as a goal of health and physical education within documents of the first national curriculum.

The Third and Fourth Republics (1963-1979) not only highlighted the spread of political ideology for maintaining 
and stabilizing the military regime but also treated economic growth as the most important goal. Accordingly, education was utilized as a powerful tool for instilling patriotic spirit, anticommunist attitudes, and national identity. Meanwhile, the government allowed schools to creatively reconstruct their own curriculum, mentioning students' development of creativity in several subjects and extracurricular activities. However, the government's interest in creativity education was still superficial, and political atmosphere itself was not even creative.

The Fifth and Sixth Republics (1979-1993) put an emphasis on a well-rounded education for raising honest and competent Korean nationals. The cultivation of a creative nation and the development of creative thinking ability were presented as directions for organizing the national curriculum (Ministry of Education, 1981, 1987). Furthermore, the words "originality" and "creation" appeared several times in art, math, and science subjects, and "creativity" was mentioned in technology and home economics as well as in the subjects of national history and social studies.

As previously stated, developing creativity has been a part of Korean education policies for a long time. However, the process experienced a qualitative change brought about by the Kim Young-sam government in 1995. The Kim administration regarded it necessary to establish a new educational system at the national level considering social changes such as the advent of globalization in the early 1980 s and the trend of education reform in major developed countries (Park \& Ban, 2005; Kim, S., Ji, Yang, Song \& Kim, J., 2010). Accordingly, the "Education Reform Committee," a government-affiliated organization, introduced an education reform plan intended to promote globalization and an information-oriented society on May 31, 1995 (Korea Institute for Curriculum and Evaluation, 2010).

The 5.31 Education Reform aimed at allowing schools to be more autonomous while simultaneously improving school accountability. It made actual qualitative changes different from prior policies by advocating diversity education, specialized education, and user (learner or student)-centered education and by establishing an autonomous and accountable education system (Park \& Ban, 2005). Creativity played an important role as an institutional framework for the general implementation of education policies. Consequently, many education policies related to the national curriculum, textbooks, and evaluation methods were carried out in order to promote the creativity of teachers as well as students. On the basis of these changes, the subsequent governments continued to keep the basic idea of the 5.31 Reform.

\section{B. The features of the creativity agenda in its development process}

To understand the features of the creativity agenda in recent years, the researchers examined the specific creativity agendas of the respective governments. According to the results, there seemed to be two different approaches regarding the main target of creativity education. How these two perspectives manifested in each government is discussed below.

\section{1) The emergence of the creativity agenda for all students: Approaching "equity" in education}

During the Kim Young-sam government (1993-1997), and the Kim Dae-jung government (1998-2002), the recognition of the need for creativity for all people began to emerge. This realization was in response to the new twentyfirst century shift toward globalization, an informationoriented society, and a knowledge-based economic system.

Previous governments had also addressed creativity in the field of education, but these two governments put more emphasis on the necessity of creativity education than before as they viewed it to be a desperate demand of the times. The Kim Young-sam government presented "education for cultivating creativity as the first element in achieving the completion of the nation's basic education (Kang et al., 1995)." The Kim Dae-jung government also asserted that creativity education should be available to all students, claiming the development of the "creative democratic citizen" or "creative Korean" as the educational goal. This perspective implies that these governments regarded every person as having creativity, and creative ability became important for all in order to live as a "modern intellectual" and "knowledgeable laborer" in future society. Under these premises, education mainly aimed at the cultivation of creativity which included problem-solving skills, flexibility, autonomy, self-directed learning ability, an adventurous attitude, a challenging spirit, etc. In order to achieve these goals, various types of curriculums and teaching-learning methods were developed.

On the other hand, raising a few gifted children was still considered important within the context of preparing for the approaching new society. Creativity-the main element of giftedness - was highlighted in the context of gifted education (Cho et al., 1993). For example, creative problemsolving activities were considered the key method to cultivate giftedness, and creativity was the criterion used to determine gifted students. Although creativity education as a part of gifted education had been continuously stressed, creativity education for general students was considered a priority among many other educational issues.

\section{2) Desire for balance in creativity education: Between "equity" and "excellence"}

The Roh Moo-hyun government (2003-2007) was also aware of the importance of creativity education for general students. It was argued that creativity is an ability that everyone already possesses; it is not a matter of its existence but the amount or level of creativity. Accordingly, the government stressed the possibility of developing creativity in all students through the students' own will and environmental aids (Korean Educational Development 
Institute, 2006). The goal of education was to improve creative and comprehensive thinking and problem-solving skills beyond the conventional methods of study, such as simply memorizing content for tests. Creativity education was more emphasized particularly in physical education and art. In addition, instruction and evaluation methods became diversified, and the production of creative textbooks was also encouraged (Presidential Committee on Education Innovation, 2007).

At the same time, the standardization policy of education was brought into question due to the inherent difficulties in nurturing students' creative productivity (Presidential Committee on Education Innovation, 2007). For this reason, the government put great emphasis on creativity education for gifted children and carried out the Act on the Promotion of Education for the Gifted and Talented Law, Comprehensive Countermeasures for Excellence in Education '04 to identify gifted children early and cultivate their potential.

In this way, educational excellence and equity were both stressed separately. However, the government strived to defuse the tension between them. It was contended that authentic equity in education was to provide proper education to each student according to personality and not to provide uniform education (Korean Educational Development Institute, 2003). In other words, it meant that even though gifted education was not for all students, it did not violate the principle of equity. In turn, the creativity of gifted children was considered important since it presumed that "the essence of gifted education was creativity education(Korean Educational Development Institute, 2003).”

In this sense, the Roh administration was different from previous governments in that it tried to reemphasize the importance of gifted education and renew the relationship between educational excellence and equity in creativity education policies.

\section{3) The central role of the creativity agenda in school education: Beyond "equity" towards "excellence" of all}

Like previous governments, the Lee Myung-bak government (2008-2012) and Park Geun-hye government (2013-present) recognized social changes as weighty matters and placed importance on developing the creativity of students. However, these two governments distinctively brought the creativity agenda to the forefront as the key theme of governmental educational policy and put more emphasis on creativity education which targeted every student.

The Lee government, in particular, clearly suggested that the range of target students in creativity education be expanded. It was criticized that there was prejudice in that creativity education was only for a few elite students and former creativity education policies centered on gifted education (Ministry of Education and Science Technology,
2010). The government, therefore, argued that creativity was needed to not only develop the personal aptitudes and talents of every student but also as a means to solve chronic problems such as uniform and cramming education. As a result, "creative experiential activity" was newly established, and the policy of diversifying the types of high schools was implemented. In a similar vein, the Park government has also tried to educate all students to become "creativeconvergent" talented persons. However, while the Lee government tried to strengthen the linkage between science and creativity, the Park government has strived to cultivate the talented person who can create new knowledge by utilizing both humanistic imagination and scientific technology (Ministry of Education, 2014a). An integrated curriculum of liberal arts and natural sciences in high school education and one free-semester for middle school students that helps them to find their own aptitudes, which are the representative policies, have been introduced.

\section{Discussion and Conclusion}

The main purpose of this research was to explore and understand the creativity agenda reflected in Korean education policy. To achieve this purpose, the research analyzed relevant materials focusing on how the creativity agenda has been formed and its features after the 5.31 Education Reform. The first result of the analysis demonstrated that creativity had somewhat appeared in education policies beginning in the 1950s, but after 5.31 Education Reform in 1995, it started to be considered as an important agenda across subjects and education fields. Since then, it has continuously existed as an institutional framework until today.

According to the second result, after the 5.31 Reform, the five subsequent governments commonly presumed that not only gifted but all students (including general students) should be the targets of creativity education. However, the governmental perspectives diverged into three categories regarding the issue of these target students: the emergence of creativity education for all students, the desire for balance, and the central role of the creativity agenda in school education. The overall features which appeared during the development of the creativity agenda and its meanings are as follows:

At the beginning of the emergence of the creativity agenda, the concept targeted all students and attracted huge attention. This was a significant change compared to the educational policies of previous governments, but it seems that the consideration fell somewhat short of a true manifesto. After that, the Roh administration endeavored to find balance between two different types of creativity education although it appeared to have given weight to gifted education. Recently, creativity education itself has come to be an important issue in the broader educational field and has gone beyond being a subcategory of special education for the gifted. This trend indicates that although it has been always argued over which of the two groups should be the target of creativity education, the target has been expanded from a few talented students to the majority of general students. 
On the surface, this expansion means that the number of target students for creativity education has quantitatively increased. More fundamentally, it can be interpreted that the concept of creativity has been changed. In conventional creativity education as a part of gifted education, creativity was regarded as an exceptional ability in a special field that only a few could possess. However, the concept of creativity in creativity education for general students relates to solving everyday problems, developing the aptitudes of individuals. This approach can be analyzed using two different levels of creativity as argued by Kozbelt et al. (2010). One level is called "Big-C" which means grand and eminent creativity that enables the achievements of great individuals. On the other hand, "little-c" is small or daily creativity which is displayed in typical situations. Following the first definition, the range of target students in creativity education might be very narrow while the second perspective allows for the range to be expanded to include every student in the classroom. The Korean creativity agenda in education has changed in the direction of emphasizing the "little-c" level of creativity. Although it is difficult to say that one certain level of creativity is more desirable than the other, this change in target seems to be appropriate given that the essence of education is to respect every individual's potential and the characteristic of modern society where anyone can be the creator. Meanwhile, another problem which needs to be taken into consideration is that these two creativity levels might conflict or cause confusion when integrated in education policy, which can hinder consistency and integrity. Thus, it needs to be examined if the division of "Big-C" and "little-c" creativity in education policy is inevitable or if there is an efficient and appropriate method of linking these two concepts.

\section{References}

[1] Cho, N. et al. (2000). A study on the improvement of system of elementary school course book 1 ( II ) : Moral subject. Korea Institute for Curriculum and Evaluation.

[2] Cho, N. et al. (2001). A study on the development of elementary 'moral education' course books : Overall. Korea Institute for Curriculum and Evaluation.

[3] Cho, S. et al. (1993). Developing tools for identification of the science gifted high school students: creative science problem solving ability test. Korean Educational Development Institute. RR93-20.

[4] Craft, A. (2006). Fostering creativity with wisdom. Cambridge Journal of Education, 36(3), 337-350.

[5] Hong, H., Park, S., So, K., Kim, S. \& Kim, J. (1999). A study on the plan of implementing elementary school curriculum based on the 7th curriculum. Korea Institute for Curriculum and Evaluation.

[6] Kang, M. et al. (1995). Idea for educational globalization. Korean Educational Development Institute.

[7] Kim, J., Yoon, H., Hwang, H., Lee, S. \& Park, S. (1998). A study on the development of textbook model. Korea Institute for Curriculum and Evaluation.

[8] Kim, S., Ji, E., Yang, G., Song, M. \& Kim, J. (2010). The change and prospects of educational assessement policy after 5.31 Education Reform. Korea Institute for Curriculum and Evaluation. RRE 2010-3.

[9] Korea Institute for Curriculum and Evaluation (2010). Korean Educational Policy : Past, present and future (Evaluation of 5.31 Reform and vision and strategies for the future education). Seminar source book.

[10] Korea Institute for Curriculum and Evaluation (2014). Operation of 2014 KICE curriculum forum Exploring the Possibility of convergence education for cultivating creative convergence human resources in elementary and secondary education.

[11] Korean Educational Development Institute (2003). Gifted education for cultivating creative knowledge producer. RR2003-01.

[12] Korean Educational Development Institute(2006). Cultivation of creative person and establishment of effective educational system. RM2006-52.

[13] Kozbelt, A., Beghetto, R. A., \& Runco, M. A. (2010). Theories of creativity. The Cambridge handbook of creativity, 20-47.

[14] Lee, Y. et al. (2000). A study on the improvment of system of elementary school course books (II) : Science. Korea Institute for Curriculum and Evaluation.

[15] Mindham, C. (2004). Thinking across the curriculum. In Jones, R. and Wyse, D. (Eds). Creativity in the primary curriculum (pp. 126-141). London: David Fulton Publishers.

[16] Ministry of Education (1955). Elementry school curriculum. MOE notification No. 44.

[17] Ministry of Education (1963). Middle school curriculum.

[18] Ministry of Education (1973). Middle school curriculum. MOE notification No. 325.

[19] Ministry of Education (1981). High school curriculum. MOE notification No. 442.

[20] Ministry of Education (1987). Middle school curriculum. MOE notification No. 87-7.

[21] Ministry of Education (1992). Middle school curriculum. MOE notification No. 1992-11.

[22] Ministry of Education (1997). Middle school curriculum. MOE notification No. 1997-15.

[23] Ministry of Education (1998). New system of university admission and education vision 2002: creation of new school culture.

[24] Ministry of Education (2014a). 2015 Announcement on major issues in general guide lines of 2015 integrated curriculum of liberal arts and natural sciences. Press release : 2014-08-26.

[25] Ministry of Education (2014b). An Analysis on the Current Trend of $21 \mathrm{st}$ century global education reform $(I I)$ : An international comparative study on creativitycharacter education through development of noncognitive competency. Policy research.

[26] Ministry of Education and Science Technology (2008a). A study on the management strategy of 'The Korea Foundation for the Advancement of Science and Creativity' for enhancing synergy effect of fusing scientific technique, education, culture. policy research task.

[27] Ministry of Education and Science Technology (2008b). Elementry and Secondary School Curriculum. MEST notification No. 2008-148.

[28] Ministry of Education and Science Technology (2008c). Plan for school autonomy.

[29] Ministry of Education and Science Technology (2009a). Development of human resources through harmonizing creativity and consideration. (Basic plan of CreativityCharacter Education).

[30] Ministry of Education and Science Technology (2009b). Elementry and Secondary School Curriculum. MEST notification No. 2009-41.

[31] Ministry of Education and Science Technology (2010a). A source book of future education community forum. (1st: Why creative human resource?).

[32] Ministry of Education and Science Technology(2010b). Reinforcement of elementary and secondary school's creativitycharacter education. video and text materials : 2010-11-16.

[33] Ministry of Education and Science Technology (2011a). Announcement of operating plan for supporting Creative school project in 2011. Press release : 2011-02-21.

[34] Ministry of Education and Science Technology (2011b). Designation of The Korea Foundation for the Advancement of Science and Creativity as a "Educational donation center" for implementing vitalizations of educational donation. Press release : 2011-12-23.

[35] National Youth Commission (2005). KBS1 Implementation of "The Second Challenge! Reading Golden Bell". Press release : 2005-10-14.

[36] Park, Y. \& Ban, S. (2005). The Political Discourse Emerged in Education Reform Process in Korea.

[37] President Advisory Education Reform Committee (1995). Educational reform plan to establish new educational systems guided globalization and informatization era : the 2 nd president report. 
[38] President Advisory Education Reform Committee (1996a). Educational reform plan to establish new educational systems guided globalization and informatization era $\Pi$ : reference material. Annex 2.

[39] President Advisory Education Reform Committee (1996b). Educational reform plan to establish new educational systems guided globalization and informatization era $I I$ : the 3 rd president report.

[40] President Advisory Education Reform Committee (1996c). Educational reform plan to establish new educational systems guided globalization and informatization era III: the 4th president report.

[41] Presidential Committee on Education Innovation (2007). Vision and strategy of Future education for realization of learning society.

[42] Park, S., So, K., \& Cha, W. (1998). A study on the activation of primary school discretionary activities. Korea Institute for Curriculum and Evaluation.

[43] The Ministry of Education and Human Resources Development (2004). Operation of Excellence in education to 400 thousand students, $5 \%$ out of total elementary, middle and high shcool students. Press release : 2004-12-22.

[44] The Ministry of Education and Human Resources Development (2005a). "To Increase thinking skills for essay, classroom innovation is enough". Press release : 2005-08-04.

[45] The Ministry of Education and Human Resources Development (2005b). 2005 Education \& HRD Innovation Expo. Press release : 2005-05-13.

[46] The Ministry of Education and Human Resources Development (2006a). Discussion about the direction of Korean gifted education. gifted education international symposium-. Press release : 2006-10-27.

[47] The Ministry of Education and Human Resources Development (2006b). Let's achieve the dream of science! -Science buds big festival-. Press release : 2006-10-20.

[48] The Ministry of Education and Human Resources Development (2007a). Improvement plan on textbook system.

[49] The Ministry of Education and Human Resources Development (2007b). Middle school curriculum. notification No. 2007-79.

[50] The Ministry of Education and Human Resources Development (2007c). Reinforcing plan of elementary and secondary science education for developing creative human resources('08-'12).

[51] The Ministry of Education and Human Resources Development (2007d). Suggestion of vision of character education and creativity education through enforcing physical education and art education. Press release : 2007-06-13.

[52] U.H. Graneheim \& B. Lundman (2004). Qualitative content analysis in nursing research: concepts, procedures and measures to achieve trustworthiness. Nurse Education Today. Volume 24, Issue 2, Pages 105-112

[53] Yang, J., Lee, K., Ju, D. Lee, S. \& Bae, E. (2001). A study on music education goal and content system ( I ) : Quantitative approach to current state of Korean elementary and secondary music education. Korea Institute for Curriculum and Evaluation.

[54] Yoon, H. et al. (2000). A study on the development of elementary 'disciplined life education' course books. Korea Institute for Curriculum and Evaluation. 